\title{
Anatomical perspective on the loss of smell and taste sensation in SARS-CoV-2 infection
}

\author{
David Kilroy (D), Arun HS Kumar (D) \\ Veterinary Anatomy, Section of Veterinary Biosciences, School of Veterinary Medicine, University College Dublin, Belfield, Dublin, Ireland
}

\begin{abstract}
The SARS-CoV-2 virus pandemic that originated from the Wuhan region of China continues to cause major disruptions globally. Loss of smell and taste sensation is reported to be an early indicators of SARS-CoV-2 infection. We provide here an anatomical perspective highlighting the anatomical regions, epithelial cell types and receptors categories involved in facilitating SARS-CoV-2 virus entry into host organism to rationalize the early loss of smell and taste sensation observed in patients infected with SARS-CoV-2 virus. We believe the anatomical perspective on anatomical regions, epithelial cell types and receptors categories presented here will be helpful in developing functional anatomy based effective strategies for early detection of SARS-CoV-2 virus positive patients.
\end{abstract}

Keywords: anatomical-pathology; contagious; containment; coronavirus; COVID-19; SARS-CoV-2

Anatomy 2020;14(2):145-149 @2020 Turkish Society of Anatomy and Clinical Anatomy (TSACA)

\section{Introduction}

The SARS-CoV-2 virus pandemic which originated from the Wuhan region of China continues to spread at rapid rate globally. ${ }^{[1,2]}$ This rapid spread is due to lack of a early detection and isolation measures which are necessary for efficient containment of the virus especially when effective therapeutics and immunity against the virus are lacking. Epidemiological data indicates that a lower number of COVID-19 cases (https://www.worldometers.info/coronavirus/) are observed across nations that took early measures to enforce either voluntary or regulated lockdown. ${ }^{[3-7]}$ Any breach in the lockdown rapidly resulted in increase in active cases of COVID-19, which reflects the extensive contagious nature of SARS-CoV-2 virus (https://www.worldometers.info/coronavirus/). Although the pathobiology of the SARS-CoV-2 virus is not well known, it appears that the virulence of the virus is relatively lower compared to previously reported strains of coronavirus. ${ }^{[8-12]}$ For the viruses which are more contagious than virulent, the strategies to target the virus host cell attachment and entry pathways become extremely important (Figure 1). Hence, understanding the anatomical regions involved in facilitating virus access into the host system is necessary to develop effective strategies to improve virus containment.
Several anatomical structures in the face provide viable access routes for the SARS-CoV-2 virus. It is feasible for the virus to enter the host system via the eyes, ear, nose and/or mouth by attaching to the host epithelial cell receptors and overriding the biodefence systems present at each of these anatomical access routes. The interaction of the SARS-CoV-2 virus with the host epithelial cell receptors will result in a functional response similar to that evinced by activation of these receptors by specific ligands. For instance involvement of receptor systems in the nose, mouth, eyes and ears will impact the sensation of smell, taste, vision and hearing respectively. ${ }^{[1-15]}$ Loss of smell and taste sensation together with fever are reported as early symptoms in patients testing positive for SARS-CoV2. ${ }^{[16,17]}$ Loss of smell and taste sensation is referred to as anosmia and ageusia respectively. ${ }^{[16-20]} \mathrm{We}$ describe here an anatomical perspective on the loss of smell and taste sensation in patients infected with SARS-CoV-2 virus and how this may be helpful in developing the disease management strategy.

\section{Anatomy of Smell and Taste Sensation}

The sensation of smell and taste is regulated by sensory receptors on the epithelium of nasal cavity and phar- 


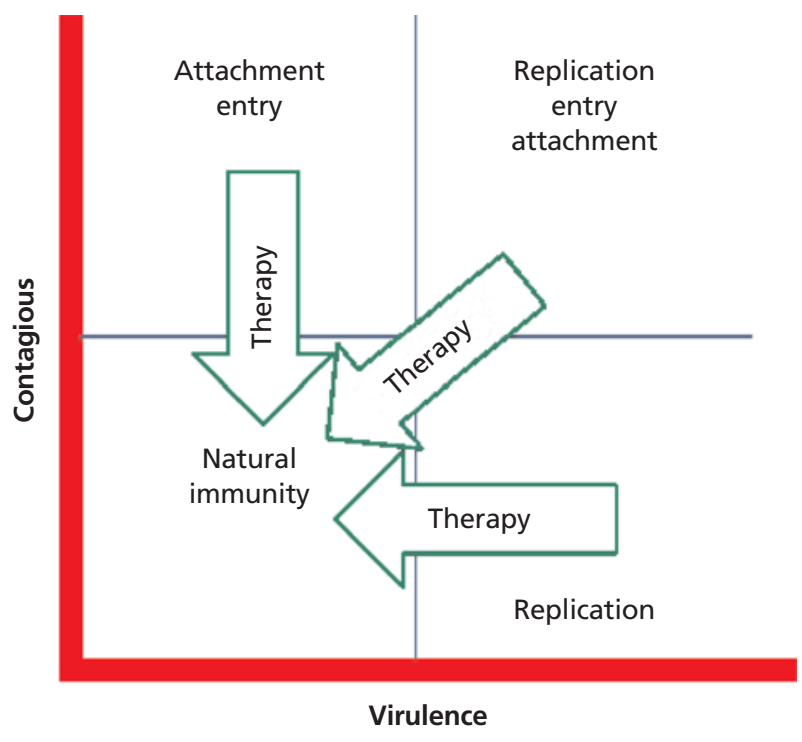

Figure 1. Classification of virus. Based on the virulence and contagious parameters, virus can be classified into four categories. These four categories should be therapeutically targeted differently. The aim of all the therapeutic strategy should be to push the virus into the category where the immune system should be able to effectively overcome the virus.

ynx.$^{[21,2]}$ Respiratory epithelium lining the nasal cavity is innervated by branches of the trigeminal nerve (cranial nerve $\mathrm{V}$ ). The nasal septum and the epithelium lining the lateral nasal wall are supplied by the ethmoidal nerves. ${ }^{[23-25]}$ The sphenopalatine ganglion, located near the middle turbinate, innervates the posterior nasal cavity and contributes to the sensory supply to the nasal septum via its nasopalatine branch. Sensory innervation of the anterior region of pharynx is by the palatine nerves, which are derived from the maxillary nerve (branch of cranial nerve V). Pharyngeal branches of the glossopharyngeal nerve (cranial nerve IX) and the vagus nerve (cranial nerve $\mathrm{X}$ ) innervate the posterior pharynx, while the laryngopharynx is supplied by the superior, middle and inferior laryngeal branches of the vagus nerve (cranial nerve $\mathrm{X}$ ). ${ }^{[26]}$

Olfactory nerve (cranial nerve I) transmits the sensation of smell to the brain. Olfaction begins by the binding of odoriferous molecules to specific $G$ protein-coupled odorant receptors which leads to their identification. ${ }^{[32,25]}$ Species with a well-developed sense of olfaction, such as rats, have about 1400 olfactory receptor (OR) genes, whereas other mammals have fewer OR genes (cows 1000; dogs 800) but have a more extensive olfactory epithelium. ${ }^{[27-30]}$ Humans have approximately 350 OR genes but have a dense network of receptors within the olfactory bulb. ${ }^{[29-31]}$ Olfactory pathways arise in the two olfactory regions of the nasal cavity which contains receptor neurons, supporting cells, basal cells and microvillus cells. Olfactory neurons convey the sensory information from the nasal cavity to the olfactory cortex of brain. The dendrites of olfactory neurons innervate the deeper layer of the olfactory epithelium. The axons of the bipolar olfactory neurons tunnel through the cribriform plate of the ethmoid bone and piriform lobes and eventually terminate on mitral cells in the olfactory bulbs. Other axons project to the hypothalamus and amygdala, components of the limbic system and regulate the influence of smell on behaviour and memory. The regenerative capacity of the olfactory neurons is very high i.e., every 3-4 weeks and is regulated by their direct and frequent contact with antigens. ${ }^{[29-31]}$

Taste receptors are specialised epithelial cells found in taste buds which are most numerous on the papillae (circumvallate and fungiform) of the dorsal surface of the tongue..$^{[1,21,24,25]}$ Smaller numbers of receptors which sense taste are present on the soft palate, the pharynx and the upper part of the oesophagus. ${ }^{[32,33]}$ These receptors synapse with dendrites of following three cranial nerves: (1) the chorda tympani of the facial nerve (cranial nerve VII) conveys the stimulus of taste from the rostral two thirds of the tongue; (2) the lingual branch of the glossopharyngeal nerve (cranial nerve IX) carries taste sensation from the caudal one third of the tongue; and (3) the superior laryngeal branch of the vagus nerve (cranial nerve $\mathrm{X}$ ) innervates the soft palate, epiglottis and oesophagus. ${ }^{[1,2,25]}$ The axons of these bipolar sensory neurons project to the nucleus of the solitary tract in the medulla oblongata which conveys information to the thalamus and then to the insular cortex. The taste receptors present in the tongue are limited by their range of perception (salt, sweet, sour, bitter, umami). Taste sensation is often supplemented by additional information from the olfactory system, which perhaps is the reason for synergy observed between anosmia (loss of sensation of smell) and ageusia (loss of taste sensation).

The exclusive observation of anosmia and ageusia in COVID-19 patients suggests that the nose and mouth are the predominant anatomical regions for the SARS-CoV-2 virus to access the host system (Figure 2). Interestingly the recovery of smell and taste sensation was reported to be very rapid in COVID-19 patients. About $80 \%$ of the patients recovered smell sensation within 8 days following resolution of the COVID-19. ${ }^{[1,17]}$ The rapid recovery may be attributed to the high regenerative activity of nasal and oral epithelium. The rapid recovery from anosmia and ageusia may also suggests that the interaction of SARSCoV-2 virus with the nasal and oral epithelium is only transient, with the speculation of neurotropic and neuroinvasive nature of SARS-CoV-2 reported in the literature being unlikely. ${ }^{[2,9,10]}$ 


\section{Anatomical Rationale for Differences in Symptoms of Anosmia and Ageusia}

Compared to all the reported symptoms observed in COVID-19 infection, anosmia and/or ageusia was reported to have the highest association with a COVID-19 positive diagnosis. ${ }^{[16,17]}$ Approximately $70 \%$ of the patients with SARS-CoV-2 infection are reported to be asymptomatic, while $68-88 \%$ of COVID-19 patients are reported to have anosmia and/or ageusia. ${ }^{[16,17,20]}$ Differences in the incidence of anosmia and ageusia among the COVID-19 patients are also described. Consistent with reported sex differences in the physiology of smell and taste sensation, female patients were reported to be significantly more affected by anosmia and/or ageusia than males. ${ }^{[16,17,20]}$ The majority of patients were reported to have severe anosmia rather than ageusia. Understanding the biological basis of this differential symptomology for the containment will be helpful in developing effective strategies for containment of SARS-CoV-2 virus. One possible reason for difference in the symptoms of anosmia and ageusia may be the anatomical differences in olfactory versus taste receptors in the path of virus entry and replication. The olfactory receptors are exclusively on the nasal epithelium, while the taste receptors are predominantly on the tongue rather than the pharyngeal epithelium. ${ }^{[15,21,30-32]}$ SARS-CoV-2 virus is reported to predominantly replicate in the pharyngeal epithelium prior to migrating into the lung parenchyma. ${ }^{[34]}$ In contrast symptom of sore throat is negatively associated with the COVID-19, suggesting that SARS-CoV-2 virus doesn't infect laryngeal or tracheal epithelium. Deciphering the biological basis for the preferential replication of the SARS-CoV-2 virus in the pharyngeal epithelium rather than other regions of the respiratory tract will be interesting and necessary to explore effective strategies to contain SARS-CoV-2 virus.

Anosmia and ageusia are symptoms commonly associated with a wide range of viral infections including COVID-19. ${ }^{[35,36]}$ However the mechanisms responsible for the sensory suppression by SARS-CoV-2 are not well known. Besides the impairment of the sensory receptors on the epithelium, trans-neural penetration through the cribriform plate to reach and functionally impair the olfactory bulb is also reported. ${ }^{[37]}$ Some studies have also suggested the role of inflammation of the supporting cells and vascular pericytes of the olfactory epithelium at the olfactory region triggering symptoms of anosmia. ${ }^{[35,36,37]}$ However, considering the rapid recovery from anosmia in COVID19 patients and lack of significant nasal inflammatory symptoms, the involvement of the olfactory bulb and/or inflammatory process seems to be unlikely. Over 380 human olfactory receptors are known ${ }^{[38]}$ and as COVID-19 patients are reported to experience a generalised loss of

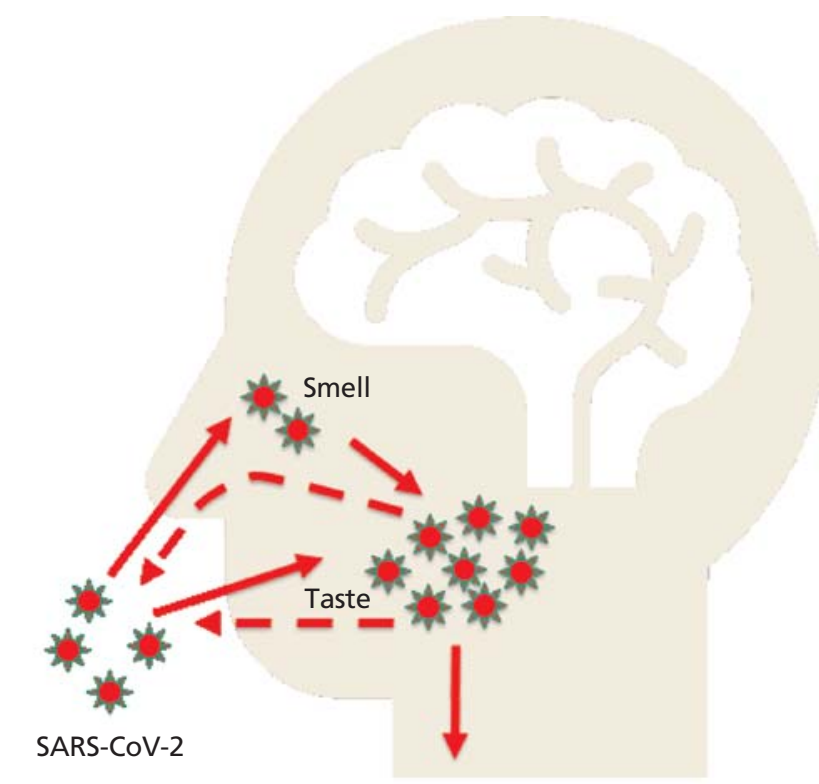

Figure 2. Entry and exit route of SARS-CoV-2 virus. Nose and mouth are the major access routes for SARS-CoV-2 virus. The virus has temporary niche in the nasal cavity and primarily replicates in the epithelial cells of pharynx before distributing to rest of the body.

smell, it is also unlikely that SARS-CoV-2 virus may show any selectivity for specific type of human olfactory receptors. This non-selectivity together with the transient nature of anosmia suggests that the anosmia experienced by COVID-19 patients is a consequence to the SARS$\mathrm{CoV}-2$ virus transiently interacting with the epithelial cells during its passage via the nasal cavity to the pharynx. The angiotensin-converting enzyme 2 (ACE2) receptor and its network proteins, which are used by SARS-CoV-2 virus to attach and enter into the host cells, are widely expressed on the epithelial cells lining the nasal cavity and pharynx. ${ }^{[39,40]}$ Hence as the SARS-CoV-2 enters the nose it finds a red carpet welcome in the epithelial lining of the nose, as these cells are rich in surface receptors (ACE2 network proteins) which provide anchorage to the virus surface proteins eventually leading to the entry of the virus into the host cell (epithelium). Once inside the host cell, the virus hijacks the cell's biochemical machinery to make multiple copies of itself, increasing its potential to invade new cells. This predominantly happens in the epithelial cells of pharynx in case of SARS-CoV-2 virus. The increased virus load in the pharynx has a two way choice (Figure 2); (1) allowing the virus to either exit (potentially infecting other hosts) and/or (2) enter deeper into the host body leading to subsequent pathogenesis. ${ }^{[41]}$ Nevertheless it will be necessary to further validate the underlying pathology of SARS-CoV-2 infection including the anosmia and ageusia in suitable experimental models. 


\section{Conclusion}

Cough, fever, myalgia, and loss of appetite are the most prevalent general symptoms reported among COVID-19 patients. ${ }^{[16,17]}$ The loss of appetite may be a secondary consequence to anosmia and/or ageusia. Considering the consistency in the COVID-19 symptoms observed, fever together with chemosensory impairment (anosmia and/or ageusia) can be used as an early detection parameters to rapidly and reliably identify and isolate patients with COVID-19. The recovery of chemosensation may be additionally used as a prognostic marker. The merit of using anosmia and/or ageusia as a primary screening or prognostic tool may have an advantage especially in overstretched health care systems. We believe our report giving an anatomical perspective highlighting the role of anatomical regions, epithelial cell types and receptors categories in the loss of smell and taste sensation in SARS$\mathrm{CoV}-2$ positive patients based on the current knowledge on pathobiology of the virus merits its application for optimal clinical management of COVID-19.

\section{Conflict of Interest}

None of the authors has any conflicts of interest to declare.

\section{Author Contributions}

DK: prepared the content on the neuro anatomy of smell and taste sensation. AK: conceptualized this report and wrote the content on SARS-CoV-2 and its interaction with neuro anatomy of smell and taste sensation.

\section{Acknowledgements}

Research support from University College Dublin-Seed funding (AHSK), Output Based Research Support Scheme (AHSK; DK), Royal Society-UK (AHSK) and Stemcology (AHSK) is acknowledged.

\section{References}

1. Andersen KG, Rambaut A, Lipkin WI, Holmes EC, Garry RF. The proximal origin of SARS-CoV-2. Nat Med 2020;26:450-2.

2. Rabi FA, Al Zoubi MS, Kasasbeh GA, Salameh DM, Al-Nasser AD. SARS-CoV-2 and Coronavirus disease 2019: what we know so far. Pathogens 2020;9:231.

3. Ferretti L, Wymant C, Kendall M, Zhao L, Nurtay A, AbelerDorner L, Parker M, Bonsall D, Fraser C. Quantifying SARSCoV-2 transmission suggests epidemic control with digital contact tracing. Science 2020;368:eabb6936.

4. Kumar M, Taki K, Gahlot R, Sharma A, Dhangar K. A chronicle of SARS-CoV-2: Part-I - epidemiology, diagnosis, prognosis, transmission and treatment. Sci Total Environ 2020;734:139278.

5. Tobias A. Evaluation of the lockdowns for the SARS-CoV-2 epidemic in Italy and Spain after one month follow up. Sci Total Environ 2020;725:138539.
6. Jung F, Krieger V, Hufert FT, Kupper JH. How we should respond to the Coronavirus SARS-CoV-2 outbreak: a German perspective. Clin Hemorheol Microcirc 2020;74:363-72.

7. Salje H, Tran Kiem C, Lefrancq N, Courtejoie N, Bosetti P, Paireau J, Andronico A, Hoze N, Richet J, Dubost CL, Le Strat Y, Lessler J, Levy-Bruhl D, Fontanet A, Opatowski L, Boelle PY, Cauchemez S. Estimating the burden of SARS-CoV-2 in France. Science 2020;369:208-11.

8. Brufsky A. Distinct viral clades of SARS-CoV-2: implications for modeling of viral spread. J Med Virol 2020;92:1386-90.

9. Ceccarelli M, Berretta M, Venanzi Rullo E, Nunnari G, Cacopardo B. Differences and similarities between Severe Acute Respiratory Syndrome (SARS)-CoronaVirus (CoV) and SARS$\mathrm{CoV}-2$. Would a rose by another name smell as sweet? Eur Rev Med Pharmacol Sci 2020;24:2781-3.

10. Dilcher M, Werno A, Jennings LC. SARS-CoV-2: a novel deadly virus in a globalised world. N Z Med J 2020;133:6-11.

11. Abdullahi IN, Emeribe AU, Mustapha JO, Fasogbon SA, Ofor IB, Opeyemi IS, Obi-George C, Sunday AO, Nwofe J. Exploring the genetics, ecology of SARS-COV-2 and climatic factors as possible control strategies against COVID-19. Infez Med 2020;28:16673.

12. Benvenuto D, Angeletti S, Giovanetti M, Bianchi M, Pascarella S, Cauda R, Ciccozzi M, Cassone A. Evolutionary analysis of SARSCoV-2: how mutation of Non-Structural Protein 6 (NSP6) could affect viral autophagy. J Infect 2020;81:e24-e27.

13. Silverthorn DU, Ober WC, Garrison CW, Silverthorn AC, Johnson BR. Human physiology: an integrated approach. 7th ed. San Francisco (CA): Pearson/Benjamin Cummings; 2010. p. 1-960.

14. Fox S. Human physiology. 14th ed. Boston (MA): McGraw-Hill Education; 2015. p. 1-832.

15. Widmaier EP, Raff H, Strang KT, Vander AJ. Vander's Human physiology: the mechanisms of body function. 13th ed. Boston (MA): McGraw-Hill Higher Education; 2008. p. 1-800.

16. Lechien JR, Chiesa-Estomba CM, De Siati DR, Horoi M, Le Bon SD, Rodriguez A, Dequanter D, Blecic S, El Afia F, Distinguin L, Chekkoury-Idrissi Y, Hans S, Delgado IL, Calvo-Henriquez C, Lavigne P, Falanga C, Barillari MR, Cammaroto G, Khalife M, Leich P, Souchay C, Rossi C, Journe F, Hsieh J, Edjlali M, Carlier R, Ris L, Lovato A, De Filippis C, Coppee F, Fakhry N, Ayad T, Saussez S. Olfactory and gustatory dysfunctions as a clinical presentation of mild-to-moderate forms of the coronavirus disease (COVID-19): a multicenter European study. Eur Arch Otorhinolaryngol 2020;277: 2251-61.

17. Yan CH, Faraji F, Prajapati DP, Boone CE, DeConde AS Association of chemosensory dysfunction and COVID-19 in patients presenting with influenza-like symptoms. Int Forum Allergy Rhinol 2020;10:806-13.

18. Mayet AY. Loss of smell (anosmia) and taste (ageusia) in a patient treated with pegylated interferon alfa and ribavirin. Curr Ther Res Clin Exp 2007;68:271-7.

19. Russell B, Moss C, Rigg A, Hopkins C, Papa S, Van Hemelrijck M. Anosmia and ageusia are emerging as symptoms in patients with COVID-19: what does the current evidence say? Ecancermedicalscience 2020;14:ed98.

20. Vaira LA, Salzano G, Deiana G, De Riu G. Anosmia and ageusia: common findings in COVID-19 patients. Laryngoscope 2020;130: 1787 . 
21. Matsuo K, Palmer JB. Anatomy and physiology of feeding and swallowing: normal and abnormal. Phys Med Rehabil Clin N Am 2008;19:691-707.

22. Laitman JT, Reidenberg JS. Specializations of the human upper respiratory and upper digestive systems as seen through comparative and developmental anatomy. Dysphagia 1993;8:318-25.

23. Hamilton WJ. Textbook of human anatomy. New York (NY): Springer; 1982. p. 1- 753.

24. Marieb EN, Hoehn K. Human anatomy and physiology. 11th ed. San Francisco (CA): Pearson Education; 2018. p. 1-1264.

25. Guyton AC. Basic neuroscience: anatomy and physiology. 2nd ed. Philadelphia (PA): Saunders; 1991. p. 1-393.

26. Mu L, Sanders I. Sensory nerve supply of the human oro- and laryngopharynx: a preliminary study. Anat Rec 2000;258:406-20.

27. Lancet D, Ben-Arie N. Olfactory receptors. Curr Biol 1993;3:66874.

28. Lancet D, Ben-Arie N, Cohen S, Gat U, Gross-Isseroff R, HornSaban S, Khen M, Lehrach H, Natochin M, North M. Olfactory receptors: transduction, diversity, human psychophysics and genome analysis. Ciba Found Symp 1993;179:131-41.

29. Olender T, Jones TEM, Bruford E, Lancet D. A unified nomenclature for vertebrate olfactory receptors. BMC Evol Biol 2020;20: 42.

30. Pilpel Y, Sosinsky A, Lancet D. Molecular biology of olfactory receptors. Essays Biochem 1998;33:93-104.

31. Pifferi S, Menini A, Kurahashi T. Signal transduction in vertebrate olfactory cilia. In: A. Menini, editor. The neurobiology of olfaction Boca Raton (FL): CRC Press Taylor \& Francis; p. 203-24.

32. Nakayama A, Miura H, Shindo Y, Kusakabe Y, Tomonari H, Harada S. Expression of the basal cell markers of taste buds in the anterior tongue and soft palate of the mouse embryo. J Comp Neurol 2008;509:211-24.

33. Tomonari H, Miura H, Nakayama A, Matsumura E, Ooki M, Ninomiya Y, Harada S. Galpha-gustducin is extensively coexpressed with sweet and bitter taste receptors in both the soft palate

ORCID ID:

D. Kilroy 0000-0002-2692-8929: A. H. S. Kumar 0000-0001-8422-0219 and fungiform papillae but has a different functional significance. Chem Senses 2012;37:241-51.

34. Wolfel R, Corman VM, Guggemos W, Seilmaier M, Zange S, Muller MA, Niemeyer D, Jones TC, Vollmar P, Rothe C, Hoelscher M, Bleicker T, Brunink S, Schneider J, Ehmann R, Zwirglmaier K, Drosten C, Wendtner C. Virological assessment of hospitalized patients with COVID-2019. Nature 2020;581:4659.

35. Hummel T, Landis BN, Huttenbrink KB. Smell and taste disorders. GMS Curr Top Otorhinolaryngol Head Neck Surg 2011;10: 4.

36. van Riel D, Verdijk R, Kuiken T. The olfactory nerve: a shortcut for influenza and other viral diseases into the central nervous system. J Pathol 2015;235:277-87.

37. Netland J, Meyerholz DK, Moore S, Cassell M, Perlman S. Severe acute respiratory syndrome coronavirus infection causes neuronal death in the absence of encephalitis in mice transgenic for human ACE2. J Virol 2008;82:7264-75.

38. Schmiedeberg K, Shirokova E, Weber HP, Schilling B, Meyerhof W, Krautwurst D. Structural determinants of odorant recognition by the human olfactory receptors OR1A1 and OR1A2. J Struct Biol 2007;159:400-12.

39. Xu H, Zhong L, Deng J, Peng J, Dan H, Zeng X, Li T, Chen Q. High expression of ACE2 receptor of $2019-\mathrm{nCoV}$ on the epithelial cells of oral mucosa. Int J Oral Sci 2020;12:8.

40. Goothy SSK, Kumar AHS. Network proteins of angiotensin-converting enzyme 2 but not angiotensin-converting enzyme 2 itself are host cell receptors for SARS-Coronavirus-2 attachment. BEMS Reports 2020;6:1-5.

41. Wadman M, Couzin-Frankel J, Kaiser J, Matacic C. How does coronavirus kill? Clinicians trace a ferocious rampage through the body, from brain to toes. [Internet]. [Retrieved on May 10, 2020]. Available from: https://www.sciencemag.org/news/2020/04/howdoes-coronavirus-kill-clinicians-trace-ferocious-rampagethrough-body-brain-toes

Correspondence to: Arun HS Kumar, DVM, DBA, MVSC, PhD Veterinary Anatomy, Section of Veterinary Biosciences, School of Veterinary Medicine, University College Dublin, Belfield, Dublin-04, Ireland Phone: +35317166230 e-mail: arun.kumar@ucd.ie

Conflict of interest statement: No conflicts declared.

This is an open access article distributed under the terms of the Creative Commons Attribution-NonCommercial-NoDerivs 4.0 Unported (CC BY-NCND4.0) Licence (http://creativecommons.org/licenses/by-nc-nd/4.0/) which permits unrestricted noncommercial use, distribution, and reproduction in any medium, provided the original work is properly cited. How to cite this article: Kilroy D, Kumar AHS. Anatomical perspective on the loss of smell and taste sensation in SARS-CoV-2 infection. Anatomy 2020;14(2):145-149. 